\title{
Virus-induced exacerbations in asthma and COPD
}

\author{
Daisuke Kurai*, Takeshi Saraya*, Haruyuki Ishii and Hajime Takizawa
}

Department of Respiratory Medicine, Kyorin University School of Medicine, Mitaka, Tokyo, Japan

\section{Edited by:}

Hirokazu Kimura, National Institute of Infectious Diseases, Japan

\section{Reviewed by:}

Wei Zhang, Yele University, USA

Shinichi Sasaki, Juntendo University

Urayasu Hospital, Japan

Yoshihito Yamada, JR Tokyo General

Hospital, Japan

\section{${ }^{*}$ Correspondence:}

Daisuke Kurai and Takeshi Saraya, Department of Respiratory Medicine, Kyorin University School of Medicine, 6-20-2, Shinkawawa, Mitaka, Tokyo 1818611, Japan e-mail: kuraida@aol.com; sara@yd5.so-net.ne.jp
Chronic obstructive pulmonary disease (COPD) is characterized by chronic airway inflammation and/or airflow limitation due to pulmonary emphysema. Chronic bronchitis, pulmonary emphysema, and bronchial asthma may all be associated with airflow limitation; therefore, exacerbation of asthma may be associated with the pathophysiology of COPD. Furthermore, recent studies have suggested that the exacerbation of asthma, namely virus-induced asthma, may be associated with a wide variety of respiratory viruses. COPD and asthma have different underlying pathophysiological processes and thus require individual therapies. Exacerbation of both COPD and asthma, which are basically defined and diagnosed by clinical symptoms, is associated with a rapid decline in lung function and increased mortality. Similar pathogens, including human rhinovirus, respiratory syncytial virus, influenza virus, parainfluenza virus, and coronavirus, are also frequently detected during exacerbation of asthma and/or COPD. Immune response to respiratory viral infections, which may be related to the severity of exacerbation in each disease, varies in patients with both COPD and asthma. In this regard, it is crucial to recognize and understand both the similarities and differences of clinical features in patients with COPD and/or asthma associated with respiratory viral infections, especially in the exacerbative stage. In relation to definition, epidemiology, and pathophysiology, this review aims to summarize current knowledge concerning exacerbation of both COPD and asthma by focusing on the clinical significance of associated respiratory virus infections.

Keywords: asthma, COPD, respiratory virus, exacerbation, overlap syndrome, human rhinovirus, respiratory syncytial virus

\section{INTRODUCTION}

Asthma and chronic obstructive pulmonary disease (COPD) are very common inflammatory diseases of the airways. The World Health Organization (WHO) estimates that asthma accounts for 1 in every 250 deaths worldwide (O'Sullivan, 2005). The prevalence of asthma in developed countries is approximately $10 \%$ in adults and even higher in children, while in developing countries, the prevalence is lower but increasing rapidly (Barnes, 2008). In the case of COPD, WHO consensus reports forecast that this disorder will be ranked the third cause of mortality in the world by 2020 (Global initiative for chronic obstructive lung disease [GOLD], $\left.2013^{1}\right)$. Acute deterioration of symptoms and lung function, which often results in respiratory failure, is a so-called "exacerbation," and it is an important and severe social and medical burden in both diseases.

\footnotetext{
Abbreviations: ABPA, allergic bronchopulmonary aspergillosis; AdVs, adenoviruses; BAL, bronchoalveolar lavage; COPD, chronic obstructive lung disease CRP, C-reactive protein; $\mathrm{FEV}_{1.0}$, forced expiratory volume in 1 second; GOLD, Global initiative for chronic obstructive lung disease; HMPV, human metapneumovirus; HRV, human rhinovirus; ICS, inhaled corticosteroid; IFN, interferon; IL, interleukin; LABA, long-acting $\beta$-agonist combination; LAMA, long-acting muscarinic antagonist; LRT, lower respiratory tract; NPS, nasopharyngeal swabs; NPW, nasopharyngeal washings; OPS, oropharyngeal swabs; PEFR, peak expiratory flow rate; PIV, parainfluenza virus; RSV, respiratory syncytial virus; RTI, respiratory tract infection; RT-PCR, reverse-transcriptase polymerase chain reaction; SABA, short-acting $\beta$-agonist inhaler; TLR, toll-like receptor; TLSP, thymic stromal lymphopoietin; URT, upper respiratory tract.

${ }^{1}$ http://www.goldcopd.org/uploads/users/files/GOLD_Report_2013_Feb20.pdf
}

Respiratory viral infections are common and usually selflimiting illnesses in healthy adults and a major cause of exacerbations in patients with asthma (Figure 1) and/or COPD (Figure 2).

This review aims to summarize the clinical aspects of exacerbations in asthma and COPD from the perspective of the definition of exacerbations, epidemiology, and pathophysiology, with a special focus on the clinical significance of the presence of respiratory viruses.

\section{PATHOPHYSIOLOGY OF ASTHMA AND COPD}

Asthma and COPD are prevalent chronic pulmonary diseases characterized by chronic airway inflammation and airflow limitation. The differences between the two diseases are mainly the cellular and molecular features of airway inflammation and the degree of reversibility of airway flow limitation. Generally, reversibility of airflow limitation is incomplete in COPD, while that in asthma can be complete. Airway inflammation in asthma is characterized by allergic phenotypes, such as dense infiltration of eosinophils and $\mathrm{T}$ helper type 2 lymphocytes, associated with atopic status, while that of COPD is mainly accumulation of neutrophils, CD8positive cytotoxic $\mathrm{T}$ cells, and activated macrophages, which are caused by inhalation of harmful substances, such as smoking. With respect to the site of inflammation, asthma involves predominantly larger airways, while in COPD, inflammation affects predominantly small airways and the lung parenchyma, characterized as irreversible airway narrowing because of fibrosis around the small 


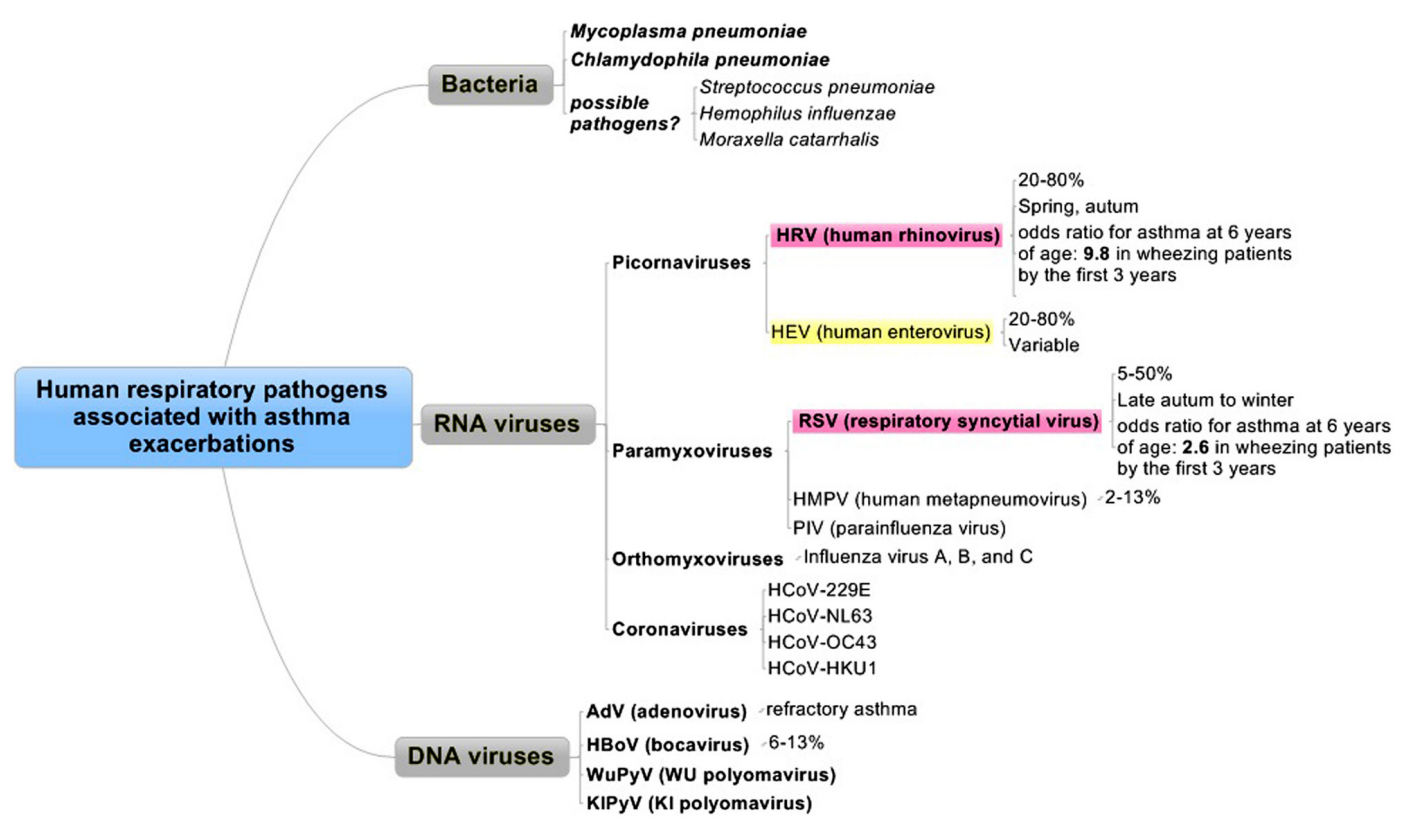

FIGURE 1 | Human respiratory pathogens associated with asthma exacerbations. Pathogens are divided into three categories as bacteria, RNA viruses, or DNA viruses. Red and yellow columns are the most relevant pathogens in order.

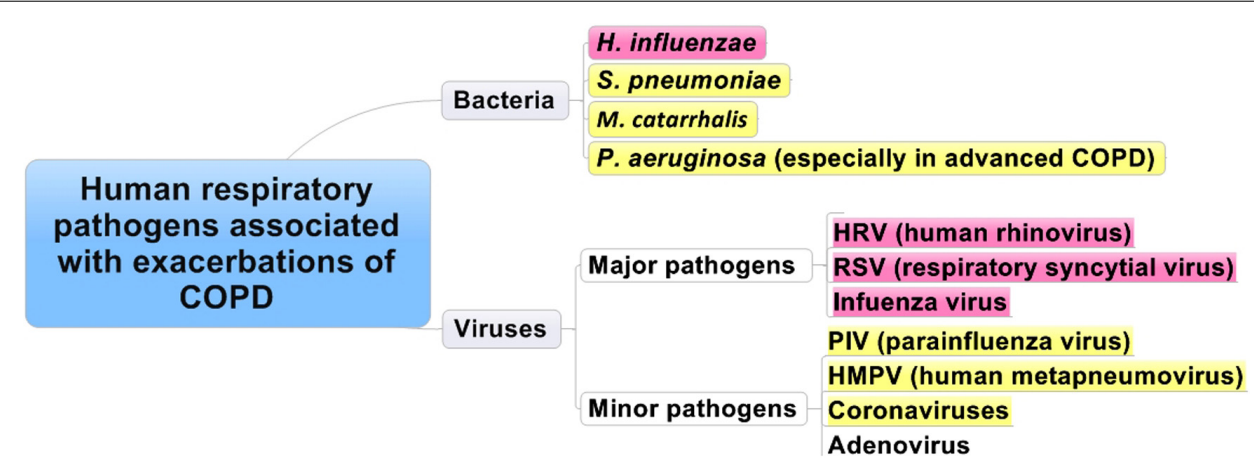

FIGURE 2 | Human respiratory pathogens associated with exacerbations of COPD. Red and yellow columns are the most relevant pathogens in order.

airways or destruction of alveolar walls with protease-mediated degradation (Barnes, 2008). Of note, neutrophilic infiltration could be recognized in bronchial biopsied specimens as well as eosinophils in severe refractory asthma (Wenzel et al., 1999).

\section{DIFFERENCES AND SIMILARITIES BETWEEN ASTHMA AND COPD}

As described above, asthma is typically characterized by chronic allergic inflammatory airway inflammation associated with airway hyperresponsiveness that leads to recurrent episodes of bronchial obstruction. In contrast, COPD is characterized by persistent airflow limitation that is usually progressive and ultimately results in respiratory failure. Therefore, it is not difficult to differentiate clinically between the two disorders. However, determining whether a patient has asthma or an exacerbation of COPD is often difficult, because of their clinical similarity. The Table 1 summarizes the differences between these two diseases, and Tokuda and
Miyagi (2007) provided an excellent review of rapid physical diagnosis for COPD patients that focused on inspection, palpation, percussion, auscultation, special maneuvers, and vital signs.

On physical examination, the sound of an expiratory wheeze is identical in asthma, COPD, congestive heart failure, and pneumonia, and it cannot be used to distinguish among these conditions (Kaplan etal., 2009). Thus, physical examination is relatively insensitive for the diagnosis of asthma, but COPD has its characteristic physical findings (Tokuda and Miyagi, 2007) that could be useful in rapid differentiation from those of asthma.

Recent understanding of the innate immune system suggests that it may function independently of the adaptive immune system in some cases or synergistically in others, and the relative contributions of the two systems may explain the disease heterogeneity among asthmatic patients, which might occur in patients with COPD (Holtzman, 2012). It has long been argued that asthma, chronic bronchitis, and emphysema could be considered 
Table 1 | Differences between asthma and COPD.

\begin{tabular}{|c|c|c|}
\hline & Asthma & COPD \\
\hline Age at onset & At any age (usually < $<0$ years) & Usually >40 years \\
\hline Smoking history & Possible & Usually > 10 pack-years \\
\hline Cough at exacerbation & Usually between 2 and 6 am & Gradual increase \\
\hline Sputum production & Infrequent & Common \\
\hline Allergy(eczema or allergic rhinitis) & Common & Infrequent \\
\hline \multicolumn{3}{|l|}{ Airway inflammation } \\
\hline Main portion & Large airways & Small airways \\
\hline \multirow[t]{2}{*}{ Pathophysiology } & Basement-membrane thickening & Fibrosis of small airways \\
\hline & Increased airway smooth muscle & Destruction of alveolar walls \\
\hline \multirow[t]{2}{*}{ Bronchial biopsies } & Th2-dominant $T$ cells & Th1-dominant T cells and type1 CTL \\
\hline & Eosinophils, activated mast cells & Neutrophils and $M \varphi$ \\
\hline Reversibility (peak flow results) & Normalize with time & May improve, but do not normalize \\
\hline Family history & Common & Uncommon \\
\hline
\end{tabular}

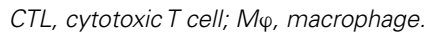

as different expressions of one disease entity. This view is called the "Dutch hypothesis" (Kraft, 2006), and it is still under debate, with no consensus about it. There are many similarities in asthma and COPD (Bleecker, 2004), and previous studies suggested that asthma may be a risk factor for the development of COPD (Silva et al., 2004), while the coexistence of asthma and COPD, so-called "overlap syndrome," has recently been attracting attention. Overlap syndrome accounts for about $15-25 \%$ of obstructive airway disease (Louie etal., 2013) and shows more frequent or severe exacerbations and higher mortality than COPD alone (Hospers et al., 2000; Hardin et al., 2011). Furthermore, previous reports noted that exacerbations of asthma or COPD are associated with accelerated loss of lung function and quality of life and increased healthcare costs and mortality.

Thus, it is crucial to recognize and understand the clinical features of asthma and COPD patients, not only in the stable phase, but also in exacerbated phases associated with respiratory viral infections. Johnston and Sears (2006) reported that exacerbations of asthma and COPD appear to have a seasonal predilection in a similar fashion.

\section{VIRUS-INDUCED EXACERBATIONS IN ASTHMA AND COPD VIRUS-INDUCED EXACERBATIONS IN ASTHMA}

In bronchial asthma, acute exacerbation involves several issues

(Figure 3), such as the definition of acute exacerbation of asthma, recognition of the clinical symptoms of respiratory tract infection (RTI), assessment of the risk factors for acute exacerbation, considering the possibility of other diseases (differential diagnosis), diagnostic methods, appropriate sample collection, and treatment or prevention. An older study showed that asthmatic patients had a 6.2 times greater chance of having viral RTIs than a control group (Abramson etal., 1994), while Corne et al. (2002) found that the detection rates of human rhinovirus (HRV) in asthmatic $(10.1 \%)$ and healthy participants $(8.5 \%)$ were similar. The term virus-induced exacerbation of asthma is not uncommon, but only a small number of such studies were prospective (Nicholson et al., 1993; Johnston et al., 1995). Furthermore, RTIs do not always lead to an exacerbation, and there is little evidence that treating or preventing the infection may cure or prevent an exacerbation. In this regard, we mainly discuss the details of "viral infection and exacerbation of asthma," focusing on the accumulation of useful expertise for understanding this unfavorable condition in adult asthmatic patients.

\section{Definitions of acute exacerbation of asthma}

The diagnosis of asthma is usually defined based on history and variability of the peak expiratory flow rate (PEFR) and/or of forced expiratory volume in $1 \mathrm{~s}\left(\mathrm{FEV}_{1.0}\right)$ of at least $20 \%$, either with therapy or spontaneously. There is no clear consensus definition for asthma exacerbation; clinical trials usually define a severe exacerbation as the need for treatment with systemic corticosteroids, hospital admission, or emergency treatment for worsening asthma, or a decrease in morning peak flow $>25 \%$ baseline on two consecutive days (O'Byrne et al., 2001). According to the latest NIH National Asthma Education and Prevention Guidelines, asthma exacerbations are acute or subacute episodes of progressively worsening shortness of breath, cough, wheezing, and chest tightness, or some combination of these symptoms, characterized by decreases in expiratory airflow and objective measures of lung function (spirometry and peak flow) (National Asthma Education and Prevention Program, 2007), identical to the definition of the Global Initiative for Asthma guidelines (2012) ${ }^{2}$ (Figure 3). However, a joint task force of the American Thoracic Society and European Respiratory Society has recently defined asthma exacerbations as events characterized by a change from the patient's previous status (Reddel et al., 2009). Severe exacerbations were defined as events that require urgent action to prevent hospitalization or death, whereas moderate exacerbations were defined as the status of an asthmatic patient who required a prompt change in treatment due to being outside the patient's usual range of day-to-day asthma variation. Mild exacerbations are not defined because such events can be

${ }^{2}$ http://www.ginasthma.org/local/uploads/files/GINA_Report_March13.pdf 


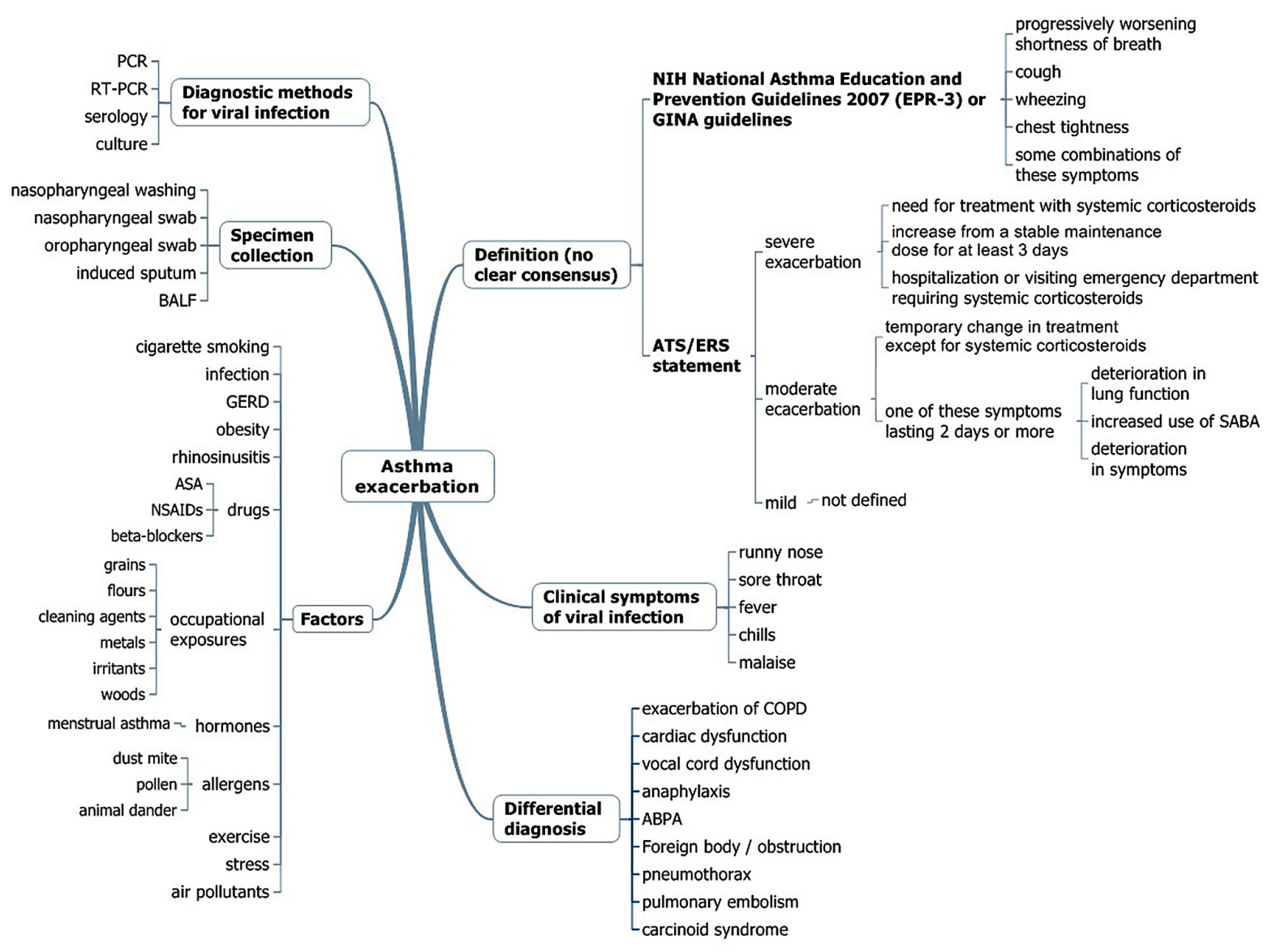

FIGURE 3 | Multidisciplinary assessment for asthma exacerbation. PCR, polymerase-chain reaction; RT-PCR, real-time PCR; BALF, bronchoalveolar lavage fluid; GERD, gastroesophageal reflux disease; ASA, acetylsalicylic acid;
NSAIDS, non-steroidal anti-inflammatory drugs; SABA, short-acting $\beta$-agonist inhalers; GINA, Global Initiative for Asthma; ABPA, allergic bronchopulmonary aspergillosis; EPR, expert panel report. indistinguishable from loss of asthma control (Reddel et al., 2009; Figure 3).

\section{Epidemiology}

Asthma exacerbations are more common in female than in male patients, and the higher prevalence of asthma in adult women contrasts with the higher prevalence of asthma in male children (Bjornson and Mitchell, 2000). Between 14 and 45\% of acute asthma exacerbations in children is thought to be related to viral RTIs. Although the incidence in adults is less clear, previous reports showed that RTIs associated with asthma exacerbation in adults ranged from 10-21\% (Teichtahl et al., 1997) to 45-80\% (Johnston et al., 1995; Atmar et al., 1998), of which 60\% have HRV (Johnston et al., 1995; Atmar et al., 1998; Tan, 2005; Figure 1). Despite their widely differing designs, these studies suggest that viral infections are involved in about $50 \%$ of asthma exacerbations among adults and in probably substantially more childhood asthma exacerbations. Another report also showed that the virus most commonly implicated in asthma exacerbations appears to be HRV (Murray et al., 2004). In addition to HRV, other respiratory tract viruses, such as respiratory syncytial virus (RSV), influenza viruses, coronaviruses, human metapneumoviruses (HMPVs), parainfluenza viruses (PIVs), adenoviruses (AdVs), and bocaviruses, have all been detected in subjects with asthma exacerbations (Jackson and Johnston, 2010). In adults requiring hospital admission for an acute severe asthma exacerbation in a 1-year period, virus was identified in $29 \%$ of the subjects, with HRV and influenza A the most commonly identified infectious agents (Teichtahl et al., 1997).

\section{Diagnosis of viral infection: diagnostic methods and sample collection}

Molecular methods of viral detection have superior sensitivity and specificity compared to cell culture-based methods (McErlean et al., 2010). In the setting of acute exacerbation, the reversetranscriptase polymerase chain reaction (RT-PCR) method can detect viruses in approximately $80 \%$ of wheezing episodes in school-aged children and in approximately one-half to threequarters of acute wheezing episodes in adults (Jackson and Johnston, 2010). With respect to sample collections for viral detection, Xiang et al. (2002) reported that nasopharyngeal secretions and induced sputum during acute exacerbations of asthma in adult patients were equal, while Falsey et al. (2012) found that the diagnostic yields using RT-PCR for detection of any virus 
in adults hospitalized with respiratory illness were superior in sputum samples $(36 \%)$ than in nose and throat swabs $(23 \%)$. However, the study had some limitations in that no test for HRV or AdVs was used. Another report showed that the sensitivity rates for oropharyngeal swabs (OPS), nasopharyngeal swabs (NPS), and nasopharyngeal washings (NPW) obtained from hospitalized patients with acute febrile lower respiratory tract (LRT) infections were 54.2, 73.3, and 84.9\%, respectively (for OPS vs. NPS and NPW, $p<0.00001$; for NPS vs. NPW, $p<0.003$; Lieberman et al., 2009). Taken together, these studies appear to suggest that induced sputum and NPS/NPW are better methods for identifying respiratory viruses. Regarding HRV, bronchoalveolar lavage (BAL) cells were positive for HRV RNA during infection in $80 \%$ of samples, whereas nasal lavage fluid was positive in the same patients in $100 \%$, and BAL fluid was positive in only $37 \%$. This suggests that HRV is able to infect the lower airways, and that HRV RNA is largely cell-associated (Murray et al., 2004).

\section{Causes of acute asthma exacerbations}

Eczema and a family history of asthma are the dominant noninfectious risk factors for pediatric asthma, while the triggers of adult-onset disease are less well defined. The causes for asthma exacerbation have been described and categorized. Of note, clinicians should recognize the seasonal trends for exacerbations of wheezing or asthma in adults, which occur 1-2 weeks later than in children, suggesting household transmission of the same strain (Johnston et al., 1996). HRV can be documented throughout the year, with a predilection for late spring and fall (Nagel et al., 2008), whereas RSV can be detected in late autumn to winter (Figure 1).

Viruses. The most important viruses relevant to asthma development are RSV and HRV. Jackson et al. (2008) demonstrated that, in a large, high-risk cohort, children had an increased risk of asthma at 6 years of age if they wheezed in the first 3 years of life with RSV [odds ratio (OR) 2.6], HRV (OR 9.8), or both HRV and RSV (OR 10).

Respiratory syncytial virus. By 1 year of age, 50-65\% of children will have been infected with this virus, and by 2 years of age, nearly $100 \%$ has been infected (Openshaw, 1995). The exact mechanisms by which respiratory viral infection causes asthma exacerbation remains to be determined, but the respiratory viruses implicated in exacerbations have themselves been largely identified (Figure 1). The role of severe RSV infection as a risk factor for asthma in adulthood is less certain, but it is still under study. RSV is an important pathogen of young children and accounts for $\sim 70 \%$ of severe infantile viral bronchiolitis and/or pneumonia cases, most of whom have wheezing, and it is the most common cause of hospital admission in the winter season during the first year of life (Blanken et al., 2013). Furthermore, this study showed the strongest evidence that human RSV-mediated bronchiolitis has long-term effects using palivizumab (a humanized monoclonal antibody against RSV F protein that prevents infection by RSV in infancy). In children under 5 years, RSV and PIV are the most common pathogens, whereas in older children, rhinovirus and influenza A virus are more prevalent (Beasley et al., 1988). Even in elderly persons, RSV causes pneumonia (Falsey et al., 2006), exacerbations of COPD, and acute deterioration in those with cardiac disease, and it contributes substantially to excess deaths in the winter season (Olszewska and Openshaw, 2009).

Human rhinovirus. Recent studies have identified infection with HRV as a predominant respiratory pathogen associated with asthma later in life (Kusel et al., 2007). HRV is the most important virus type associated with exacerbations of asthma leading to hospital admission in both adults and children (Johnston et al., 1996). Tan etal. (2003) reported that picornaviruses (rhinovirus/enterovirus) and AdV were most commonly identified in near-fatal asthma, whereas influenza virus predominated in COPD. Corne et al. (2002) found that the detection rates of HRV in asthmatic (10.1\%) and healthy participants (8.5\%) were similar, but the LRT symptoms were significantly more severe and longerlasting in the asthmatic group than in the healthy group. Thus, HRV is the most common and important cause of exacerbation in both children and adults (Johnston et al., 1996; Rakes et al., 1999; Copenhaver et al., 2004; Message et al., 2008; Dougherty and Fahy, 2009; Olenec et al., 2010; Jackson et al., 2012). HRV can now be classified into three species (HRV-A, B, and C) based on their genetic properties (http://www.ictvonline.org/), while over 100 serotypes have been identified. Molecular epidemiological studies suggest that HRV-A and -C are the major prevalent species, with wide genetic divergence (Fujitsuka et al., 2011).

Adenoviruses. Adenoviruses are well known as a primary cause of acute respiratory infection, particularly in young children. AdVs are associated with up to $7 \%$ of virus-related asthma exacerbations (McErlean et al., 2010), and they cause a wide variety of clinical syndromes, such as diarrhea, keratoconjunctivitis, and hemorrhagic cystitis (Brodzinski and Ruddy, 2009). It has been demonstrated that $94 \%$ of children with refractory asthma has detectable AdV antigens, compared with $0 \%$ of controls (Macek et al., 1994; Figure 1).

Parainfluenza virus. As previously noted, PIV is one of the most common pathogens for asthma exacerbation in children under 5 years. In adults with asthma, PIV infections have also been commonly demonstrated in several longitudinal studies of RTIs, but they have been identified less commonly in studies of patients seen in the hospital or emergency department (Atmar et al., 1998).

Other viruses. Most asthma studies describe relatively low levels of influenza viruses in asthmatic patients with exacerbations, approximately 1-9\% of all virus-related asthma exacerbations. Several studies indicated that human bocaviruses (Gendrel et al., 2007; Vallet et al., 2009) and HMPV (Williams et al., 2005; Ong et al., 2007) are associated with exacerbations of asthma, especially in children.

Bacteria. Mycoplasma pneumoniae and Chlamydophila pneumoniae are found more frequently in the airways of patients with asthma than in healthy patients (Nisar et al., 2007), but their role in exacerbations is less clear (Xepapadaki et al., 2008). In previous studies, some have reported mycoplasmal infection in up to $25 \%$ of children with wheezing (Henderson et al., 1979) or identified it in $20 \%$ of exacerbations in asthmatic children requiring hospitalization and in $50 \%$ of children experiencing their first asthmatic 
attack (Biscardi et al., 2004). However, others have not been able to confirm these observations (Cunningham et al., 1998).

Other specific pathogens, including Haemophilus influenzae, Streptococcus pneumoniae, Pseudomonas aeruginosa, Moraxella catarrhalis, HRV, and RSV, have been shown to increase mucus secretion, which is recognized in asthma or COPD by characteristic goblet cell hyperplasia or enhanced mucus secretion (Fahy, 2002; Bisgaard et al., 2007; Kraft et al., 2008).

Fungus. Allergic bronchopulmonary aspergillosis (ABPA) is a unique form of asthma caused by colonization of the LRT (Vlahakis and Aksamit, 2001). ABPA is caused by an exaggerated T helper type 2 response to the ubiquitous mold Aspergillus spp., by which colonization leads to allergic and/or asthma symptoms (Edwards et al., 2012).

Other factors. The diverse etiologies for asthma exacerbation are well known, including viruses, allergens (dust mite, pollen, animal dander), smoking, gastroesophageal reflux disease, obesity, rhinosinusitis, stress, occupational exposures, hormones (menstrual asthma), drugs (acetylsalicylic acid, non-steroidal anti-inflammatory drugs, beta-blockers), exercise, and air pollutants. Physicians should be aware of these risk factors for asthma exacerbation (Dougherty and Fahy, 2009).

\section{Mechanisms of viral-induced asthma exacerbations}

Respiratory virus infection affects the pathogenesis of asthma. Bronchial epithelial cells are at the site of respiratory virus infection and replication. Respiratory virus infection induces production of various cytokines or chemokines and causes injury to epithelial cells or disruption of tight junctions. This inflammatory process may be amplified by intrinsic factors (susceptibility gene, family history of atopy, lung development) or environmental factors (respiratory virus infection, allergen exposure, smoking, and air pollutants, etc.; Hashimoto et al., 2008; Dougherty and Fahy, 2009). Some studies showing a deficiency in interferon (IFN)- $\beta$ and IFN- $\lambda$ production in response to HRV inoculation in airway epithelial cells cultured from asthmatic versus normal subjects (Holtzman, 2012) suggested that asthmatic patients have deficient IFN- $\beta$, IFN- $\lambda$, and perhaps some of the IFN- $\alpha$, but the precise mechanism or mechanisms behind deficient IFN production in these patients remain unknown.

\section{Virus-associated clinical symptoms and exacerbations of asthma}

In general, upper respiratory tract (URT) symptoms include rhinorrhea, sneezing, blocked nose, sore throat, hoarse voice, head or face ache, chill, and fever, while LRT symptoms include symptoms such as wheeze, cough, shortness of breath, and chest tightness (Corne et al., 2002). Tan et al. (2003) reported that virus-positive patients had a significantly increased frequency of URT symptoms of rhinorrhea, sore throat, fever, chills, and malaise. Nicholson et al. (1993) reported that, in adults with asthma, about a quarter of laboratory-confirmed viral and chlamydial acute upper respiratory infections was associated with mean decreases in peak expiratory flow of $>50 \mathrm{~L} / \mathrm{min}$, and half was associated with mean decreases of $>25 \mathrm{~L} / \mathrm{min}$. The report also noted that respiratory pathogens were implicated in almost half of the most severe asthma exacerbations with a $>50 \mathrm{~L} / \mathrm{min}$ mean decrease in peak expiratory flow. Viral infections have been shown to enhance both the reactivity of the lower airway and the magnitude of bronchoconstriction in response to inhaled contractile substances in asthma. The latter effect can persist for several weeks after infection, presenting as LRT symptoms (Cheung et al., 1995) accompanied by a decrease in peak expiratory flow. Thus, physicians should be aware of decreased peak expiratory flow, URT, or LRT symptoms associated with viral infections.

\section{Treatment}

The term "virus-induced exacerbation" is not uncommon, but only a small number of prospective studies have been conducted so far (Nicholson et al., 1993; Johnston et al., 1995). Importantly, respiratory infections do not always result in an exacerbation, and there is little evidence that treating or preventing the infection may cure or prevent an exacerbation (Xepapadaki and Papadopoulos, 2010). However, another study found that URT infections were strongly associated with exacerbations of asthma leading to hospital admission, in both adults and children (Johnston et al., 1996), and they may have contributed to asthma mortality, especially in the setting of hospital admission. Specific anti-viral therapies have not been established except for influenza viral infection, which have been recommended for persons with asthma or COPD. Furthermore, regarding preventive therapy for RSV, palivizumab as described above is now commercially available, and it might be appropriate for infants and young children with congenital heart disease, bronchopulmonary dysplasia, and prematurity before 35 weeks of gestation (Dawson-Caswell and Muncie, 2011). Blanken et al. (2013) stated that palivizumab treatment in healthy preterm infants born at a gestational age of 3335 weeks reduced the number of wheezing days during the first year of life.

In this regard, several therapeutic strategies would need to be taken early in the course of infection to maximize the effects of treatments such as systemic corticosteroids, antibiotics if necessary, and short-acting $\beta$-agonist inhalers (SABAs), followed by inhaled corticosteroid (ICS) and long-acting $\beta$-agonist combination (LABA) therapy. Kerstjens et al. (2012) reported that additive long-acting muscarinic antagonist (LAMA) therapy with tiotropium (known as a cornerstone of COPD treatment) significantly increased the time to the first exacerbation and improved $\mathrm{FEV}_{1.0}$ in poorly controlled asthmatic patients with standard therapy (ICS and LABA). Similarly, tiotropium improved lung function and reduced the chance of rescue inhaler (SABA) in patients with overlap syndrome (Magnussen et al., 2008).

\section{VIRUS-INDUCED EXACERBATIONS IN CHRONIC OBSTRUCTIVE PULMONARY DISEASE DEFINITION OF EXACERBATION IN COPD}

Exacerbation of COPD is an event characterized by an acute increase in respiratory symptoms beyond normal day-to-day variation (Vestbo et al., 2013). Clinicians and researchers should always keep in mind that exacerbations of COPD are neither defined consistently nor matched in individual studies. Definitions of exacerbations are roughly divided into two groups, event-based exacerbations and symptom-based exacerbations, depending on 
the patients' symptoms or clinical events, respectively. Symptoms were defined and include dyspnea, cough, and sputum volume or purulence. Clinical events were defined as a status requiring additional treatments such as systemic antimicrobials or steroids with or without admission. Diseases such as pneumonia, congestive heart failure, and pulmonary embolism that mimic and/or aggravate exacerbations were generally excluded from exacerbations of COPD.

\section{CLINICAL IMPORTANCE OF EXACERBATION}

The clinical course of COPD, as well as that of asthma, is punctuated by exacerbations, which are characterized by sudden symptom worsening beyond the expected daily variation. Exacerbations are important events in the clinical course of COPD, because they are associated with significant mortality. The inhospital mortality rate of patients admitted to the hospital with exacerbations of COPD was $8 \%$, increasing to $23 \%$ after 1 year of follow-up (Groenewegen et al., 2003). Exacerbations are correlated with accelerated loss of lung function and quality of life and increased healthcare costs (Seemungal et al., 1998; Donaldson et al., 2002; Miravitlles et al., 2002).

\section{FREOUENCY OF EXACERBATIONS}

Previous studies showed that the annual rate of event-based exacerbations of COPD was $0.85-1.30$ per patient per year (Calverley et al., 2007; Tashkin et al., 2008; Wedzicha et al., 2008; Seemungal et al., 2009; Hurst et al., 2010). The INSPIRE study showed that the rate of symptom-based exacerbations was about two times as high as that of event-based exacerbations (Seemungal et al., 2009). In the ECLIPSE study, the exacerbation rates were 0.85 per person for patients with moderate disease (GOLD stage 2) and 2.00 for those with very severe disease (GOLD stage 4; Hurst et al., 2010). Thus, the rate of exacerbation seems to depend on the disease severity (GOLD stage). However, it is particularly worth noting that the ECLIPSE study showed a subgroup of COPD patients that appeared to be susceptible to exacerbations, irrespective of GOLD stage. Other factors for exacerbations were several environmental factors, such as seasons or inhalation of harmful substances, and epidemic peaks in exacerbations of COPD were noted in both late fall and winter in the same fashion as in adult asthma (Johnston and Sears, 2006).

\section{CAUSES OF EXACERBATIONS}

It has been reported that exacerbations are predominantly caused by bacterial and viral respiratory infections (Figure 2), and air pollution has a minor contribution. Previous studies showed that bacteria (H. influenzae, S. pneumoniae, Moraxella catarrhalis, and $P$. aeruginosa) and respiratory viruses (HRV, RSV, influenza virus, HMPV, coronavirus, and AdVs) were recognized during exacerbations. Bacteria, such as $H$. influenzae, S. pneumoniae, Moraxella catarrhalis, and $P$. aeruginosa were also detected in stable patients (Sapey and Stockley, 2006; Sethi and Murphy, 2008). When strains of bacteria are changed among the same species or there is emergence of other bacteria, this might cause inflammation in the lung in COPD patients and result in exacerbation (Sethi et al., 2002). The role of atypical respiratory pathogens, such as Mycoplasma pneumoniae and C. pneumoniae, in exacerbations of COPD is poorly recognized (Sapey and Stockley, 2006; Sethi and Murphy, 2008; Perotin et al., 2013). On the other hand, Blasi et al. (2002) showed that $C$. pneumoniae may be associated with exacerbation of COPD. Viruses such as HRV, RSV, and influenza virus have a higher prevalence in patients with exacerbations of COPD than in stable patients (Rohde et al., 2003; Wilkinson et al., 2006a).

\section{ROLES OF RESPIRATORY VIRAL INFECTION IN COPD EXACERBATIONS}

A few decades ago, it was considered that the role of respiratory viral infections was not a major cause in exacerbations of COPD because of the low sensitivity for viral detection, which depended on conventional technical methods such as viral culture or serological tests. However, recent studies have used new diagnostic technologies such as PCR or RT-PCR methods, which have a higher sensitivity for viral detection than conventional methods. Viral detections accounted for $22-57 \%$ of exacerbations of COPD in recent studies(Figure 4) using PCR or RT-PCR with observational periods of at least 1 year. The major viruses associated with exacerbations were HRV (3.1-26.6\%), RSV (0.7-40.5\%), and influenza virus (2.0-22.4\%; Seemungal et al., 2001; Rohde et al., 2003; Tan et al., 2003; Beckham et al., 2005; Papi et al., 2006; Hutchinson etal., 2007; Ko etal., 2007; McManus et al., 2008; Kherad et al., 2010; Dimopoulos et al., 2012; Perotin et al., 2013).

Major respiratory viruses detected during exacerbations of COPD were HRV, RSV, and influenza virus, similar to those of

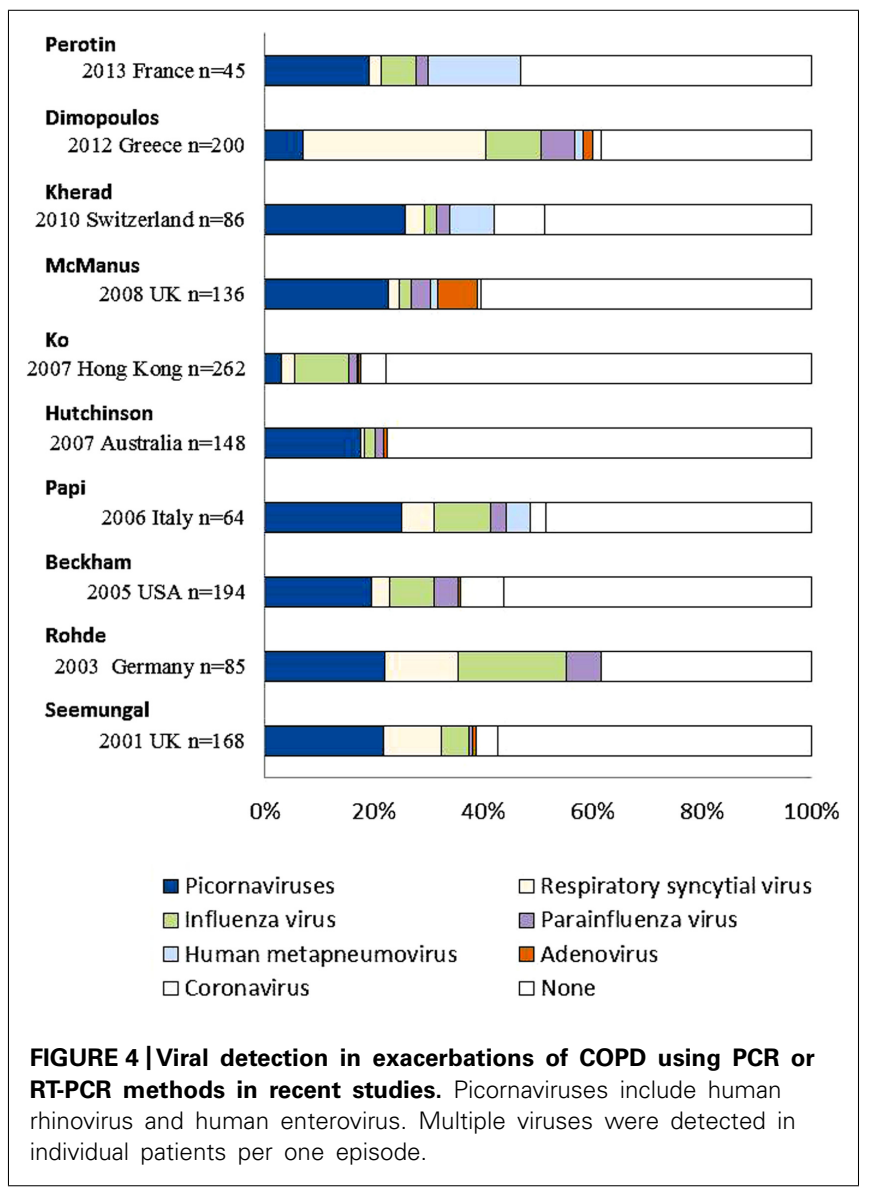


asthma (Tan etal., 2003). Other viruses, such as PIV, human metapneumovirus, AdV, and coronavirus, were also noted in patients with COPD exacerbations. The proportion of viralrelated exacerbations seemed to be similar among the various GOLD stages, while that of bacteria-related exacerbations increased with higher stage or a decrease in lung function (Dimopoulos et al., 2012).

\section{HRV}

Human rhinovirus was the most detected virus during exacerbations of COPD, but not only HRV infection alone but also co-infection with HRV and bacteria may cause exacerbations (Wilkinson et al., 2006b). Mallia et al. (2011) reported that experimental HRV infection showed more severe and prolonged lower respiratory symptoms, airway obstruction, and neutrophilic airway inflammation in COPD patients than in control subjects. They stated that rhinovirus infection led to elevation of neutrophil elastase, which is associated with reduction of antimicrobial peptides, such as secretory leukoprotease inhibitor and elafin. This reduction of antimicrobial peptides predisposes to secondary bacterial infection (Mallia et al., 2011, 2012).

Previous reports showed that COPD exacerbations may be associated with an impaired host response to HRV. For example, reduced IFN production was observed in COPD patients compared to control subjects, which may be associated with the mechanism of viral and subsequent bacterial infection related to severe exacerbations. Impaired humoral immunity was also related to exacerbation of COPD. Patients hospitalized with COPD exacerbations had lower serum levels of rhinovirus-specific antibodies than those not hospitalized with COPD exacerbations (Yerkovich et al., 2012). Thymic stromal lymphopoietin (TSLP) is a key pro-allergic cytokine that has recently been linked to asthma(Redhu and Gounni, 2012). In addition, genome-wide association studies showed that polymorphisms near or within the TSLP gene were associated with various allergic diseases, including bronchial asthma (Hirota et al., 2011; Ober and Yao, 2011). TSLP may contribute to exacerbations of the pathogenic effects of HRV infection via a Toll-like receptor (TLR)3-dependent pathway (Calven et al., 2012).

\section{RSV}

Respiratory syncytial virus has been detected in both stable and exacerbated cases of COPD. RSV detection in stable COPD patients might be associated with insidious airway inflammation and accelerated decline in $\mathrm{FEV}_{1.0}$ (Wilkinson et al., 2006a). However, this was not confirmed by another study (Falsey et al., 2006). RSV increases the expression of TLR3 on the surface of airway epithelial cells, which is associated with increased sensitization to double-stranded RNA and its related infections (Groskreutz et al., 2006).

\section{Influenza virus}

Influenza virus has been associated with mortality and morbidity in chronic lung diseases (Harper et al., 2009). A meta-analysis showed that influenza vaccination prevented exacerbations in COPD patients (Poole et al., 2000) and reduced the mortality and morbidity in elderly persons (Nichol et al., 2007). Anti-viral treatment such as neuraminidase inhibitors may reduce the severity of disease (Kaiser et al., 2003). Thus, treatment to prevent influenza has been recommended for COPD patients (Harper et al., 2009).

\section{ARE PATIENTS WITH COPD SUSCEPTIBLE TO RESPIRATORY VIRAL INFECTIONS?}

Greenberg et al. (2000) investigated viral infections with or without COPD in a longitudinal cohort study. They demonstrated that annual symptomatic documented respiratory viral infection rates were similar for COPD and age-matched controls (0.45/year and 0.54/year, respectively). However, the COPD patients had more office visits and hospitalization than controls.

Of note, Mallia et al. $(2011,2012)$ confirmed these findings in a human experimental study; they found no significant differences in the frequencies of successful HRV infection between COPD and control groups when these groups were experimentally inoculated with HRV. Respiratory symptoms and a decline in lung function were more severe in the COPD group than in the control group.

\section{DIFFERENCES IN VIRAL AND NON-VIRAL EXACERBATIONS}

Several studies have suggested that respiratory virus-associated exacerbations are more critical events than those due to other causes, in that viral-detected exacerbations showed a larger decline in lung function and longer recovery time than non-viral exacerbations (Seemungal et al., 2001; Bafadhel et al., 2011). As described in the chapter on HRV, respiratory viral infections themselves exacerbated COPD patients and tended to provoke secondary bacterial infections. Viral and sequential bacterial infections may be associated with severe respiratory symptoms (Wilkinson et al., 2006b; Harper et al., 2009; Mallia et al., 2012).

\section{MECHANISMS OF VIRUS-INDUCED COPD EXACERBATIONS}

As shown in the Table 1, the pathological features of COPD are fibrosis around small airways involving several different cells (neutrophils, macrophage, CD8 lymphocytes) and destruction of lung parenchyma. Neutrophils have been found to be associated with both stable and exacerbated COPD (Hogg et al., 2004; Papi et al., 2006).

Changes in neutrophil counts during exacerbations in both sputum and peripheral blood have been found to be related to the $\mathrm{FEV}_{1.0}$ value. Levels of tumor necrosis factor-alpha and interleukin (IL)-8 in sputum were associated with neutrophilic inflammation (Keatings et al., 1996). Especially in patients who suffered from frequent exacerbations, they had persistently higher systemic IL-6 and C-reactive protein (CRP) levels, which may explain the greater decline in lung function (Perera et al., 2007).

Inflammatory cytokines in sputum during exacerbations have been found to be elevated regardless of whether the infection is viral or bacterial (Aaron et al., 2001), and their levels were higher with exacerbations than when stable. Eosinophils are considered characteristic cells in asthma, but they are also detected with exacerbations of COPD (Saetta et al., 1994). Indeed, Papi et al. (2006) demonstrated that virus-associated exacerbations in COPD patients were related to increased eosinophil counts and the level of eosinophil cationic protein. Furthermore, Bafadhel et al. (2011) showed that serum C-X-C motif chemokine 10 (CXCL10) is implicated as a more potent predictive maker for 
virus-associated exacerbations, and it is known as IFN- $\lambda$-induced protein 10 .

\section{TREATMENT OF STABLE AND EXACERBATION STATES}

Inhaled bronchodilators, LAMA and LABA, are the main pharmacological therapies in stable COPD patients (Tashkin et al., 2008; Wedzicha et al., 2008; Vestbo et al., 2013). Although Vogelmeier et al. (2011) reported that the tiotropium (LAMA)-treated group had a lower exacerbation rate than the salmeterol (LABA)-treated group in their head-to-head study, both LAMA and LABA treatments decreased exacerbation rates and improved lung function or health-related quality of life. Tashkin et al. (2009) found that combination LAMA/LABA therapy improved pulmonary function $\left(\mathrm{FEV}_{1.0}\right)$ and respiratory symptoms better than LAMA therapy alone. ICS, the main treatment for asthma, is also prescribed in COPD patients and may reduce airway inflammation and decrease exacerbation rates only in moderate and severe COPD patients (Calverley et al., 2007). Treatment with macrolide antibiotics has been reported to prevent COPD exacerbations and improve patient quality of life and symptoms, especially in patients who have frequent exacerbations (Albert et al., 2011; Yamaya et al., 2012a), although this intervention could lead to unfavorable events such as increasing the prevalence of macrolide-resistant pathogens or cardiac toxicity.

It has been estimated that most exacerbations of COPD are due to respiratory viral and/or bacterial infections. Thus, the major pharmacological components of managing exacerbations of COPD include SABAs, short-course systemic glucocorticoids, and antibiotics (Vestbo et al., 2013). However, anti-viral therapies are rarely prescribed, because specific anti-viral therapies do not exist, except for influenza virus and RSV. Treatment for influenza appears appropriate in patients with COPD (Harper et al., 2009),

\section{REFERENCES}

Aaron, S. D., Angel, J. B., Lunau, M., Wright, K., Fex, C., Le Saux, N., etal. (2001). Granulocyte inflammatory markers and airway infection during acute exacerbation of chronic obstructive pulmonary disease. Am. J. Respir. Crit. Care Med. 163, 349-355. doi: 10.1164/ ajrccm.163.2.2003122

Abramson, M., Pearson, L., Kutin, J., Czarny, D., Dziukas, L., and Bowes, G. (1994). Allergies, upper respiratory tract infections, and asthma. J. Asthma 31, 367-374. doi: 10.3109/ 02770909409061316

Albert, R. K., Connett, J., Bailey, W. C., Casaburi, R., Cooper, J. A. Jr., Criner, G. J., et al. (2011). Azithromycin for prevention of exacerbations of COPD. N. Engl. J. Med. 365, 689-698. doi: 10.1056/NEJMoal1 04623

Atmar, R. L., Guy, E., Guntupalli, K. K., Zimmerman, J. L., Bandi, V. D., Baxter, B. D., et al. (1998). Respiratory tract viral infections in inner-city asthmatic adults. Arch. Intern. Med.
158, 2453-2459. doi: 10.1001/archinte.158.22.2453

Bafadhel, M., Mckenna, S., Terry, S., Mistry, V., Reid, C., Haldar, P., et al. (2011). Acute exacerbations of chronic obstructive pulmonary disease: identification of biologic clusters and their biomarkers. Am. J. Respir. Crit. Care Med. 184, 662-671. doi: $10.1164 / \mathrm{rccm}$. 201104-0597OC

Barnes, P. J. (2008). The cytokine network in asthma and chronic obstructive pulmonary disease. J. Clin. Invest. 118, 3546-3556. doi: 10.1172/ JCI36130

Beasley, R., Coleman, E. D., Hermon, Y., Holst, P. E., O'donnell, T. V., and Tobias, M. (1988). Viral respiratory tract infection and exacerbations of asthma in adult patients. Thorax 43, 679-683. doi: 10.1136/thx.43. 9.679

Beckham, J. D., Cadena, A., Lin, J. Piedra, P. A., Glezen, W. P., Greenberg, S. B., et al. (2005). Respiratory viral infections in patients with chronic, obstructive pulmonary

while the utility of treatment for RSV has not been confirmed in adults. It is doubtful that systemic corticosteroid treatment affects the clinical course of respiratory viral infections. Lee et al. (2011) showed that short-course systemic steroid treatment did not affect viral load or shedding, and humoral immunity may be diminished by steroid treatment.

Some research has shown that LAMA may affect viral infections. Tiotropium, one of the LAMAs, may inhibit HRV and RSV infections by reducing the levels of intercellular adhesion molecule-1, which is the binding site for most HRVs (Iesato et al., 2008; Yamaya et al., 2012b).

\section{SUMMARY AT A GLANCE}

The associations between virus infections and asthma and/or COPD were reviewed, and the significance of viral infections, as well as their effect on the clinical course, was discussed.

(1) HRV and RSV are major causes of exacerbations both in asthma and COPD patients.

(2) The frequency of viral detection in both asthma and COPD patients appears to be similar to that of healthy subjects, but the effect on their clinical course is different; asthma and COPD patients tend to have more severe or persistent respiratory symptoms or decreases in pulmonary function, and mortality may be increased.

(3) Since discrimination between asthma and COPD is difficult, especially during exacerbations, whenever clinicians encounter patients in whom obstructive airway disease is suspected, multidisciplinary assessment is required for diagnosis.

(4) The clinical findings of both asthma and COPD, so-called "overlap syndrome," are commonly recognized in general practice, and virus-associated exacerbations in this disease may lead to a poor prognosis.

disease. J. Infect. 50, 322-330. doi: 10.1016/j.jinf.2004.07.011

Biscardi, S., Lorrot, M., Marc, E., Moulin, F., Boutonnat-Faucher, B., Heilbronner, C., et al. (2004). Mycoplasma pneumoniae and asthma in children. Clin. Infect. Dis 38, 1341-1346. doi: 10.1086/392498

Bisgaard, H., Hermansen, M. N., Buchvald, F., Loland, L., Halkjaer, L. B., Bonnelykke, K., et al. (2007). Childhood asthma after bacterial colonization of the airway in neonates. N. Engl. J. Med. 357, 1487-1495. doi: 10.1056/NEJMoa 052632

Bjornson, C. L., and Mitchell, I. (2000). Gender differences in asthma in childhood and adolescence. J. Gend. Specif. Med. 3, 57-61.

Blanken, M. O., Rovers, M. M., Molenaar, J. M., Winkler-Seinstra, P. L. Meijer, A., Kimpen, J. L., et al. (2013). Respiratory syncytial virus and recurrent wheeze in healthy preterm infants. N. Engl. J. Med. 368, 1791-1799. doi: 10.1056/NEJMoa1211917
Blasi, F., Damato, S., Cosentini, R., Tarsia, P., Raccanelli, R., Centanni, S., et al. (2002). Chlamydia pneumoniae and chronic bronchitis: association with severity and bacterial clearance following treatment. Thorax 57, 672676. doi: 10.1136/thorax.57.8.672

Bleecker, E. R. (2004). Similarities and differences in asthma and COPD. The Dutch hypothesis. Chest 126, 93S-95S. doi: 10.1378/chest. 126.2_suppl_1.93S

Brodzinski, H., and Ruddy, R. M. (2009). Review of new and newly discovered respiratory tract viruses in children. Pediatr. Emerg. Care 25, 352-360. doi: 10.1097/PEC. 0b013e3181a3497e

Calven, J., Yudina, Y., Hallgren, O., Westergren-Thorsson, G., Davies, D. E., Brandelius, A., et al. (2012). Viral stimuli trigger exaggerated thymic stromal lymphopoietin expression by chronic obstructive pulmonary disease epithelium: role of endosomal TLR3 and cytosolic RIG-I-like helicases. J. Innate Immun. 4, 86-99. doi: $10.1159 / 000329131$ 
Calverley, P. M., Anderson, J. A., Celli, B., Ferguson, G. T., Jenkins, C., Jones, P. W., etal. (2007). Salmeterol and fluticasone propionate and survival in chronic obstructive pulmonary disease. N. Engl. J. Med. 356, 775-789. doi: 10.1056/NEJMoa 063070

Cheung, D., Dick, E. C., Timmers, M. C., De Klerk, E. P., Spaan, W. J., and Sterk, P. J. (1995). Rhinovirus inhalation causes long-lasting excessive airway narrowing in response to methacholine in asthmatic subjects in vivo. Am. J. Respir. Crit. Care Med. 152, 1490-1496. doi: 10.1164/ajrccm.152.5.7582282

Copenhaver, C. C., Gern, J. E., Li, Z., Shult, P. A., Rosenthal, L. A., Mikus, L. D., et al. (2004). Cytokine response patterns, exposure to viruses, and respiratory infections in the first year of life. Am. J. Respir. Crit. Care Med. 170, 175-180. doi: 10.1164/rccm.200312$1647 \mathrm{OC}$

Corne, J. M., Marshall, C., Smith, S., Schreiber, J., Sanderson, G., Holgate, S. T., et al. (2002). Frequency, severity, and duration of rhinovirus infections in asthmatic and non-asthmatic individuals: a longitudinal cohort study. Lancet 359, 831834. doi: 10.1016/S0140-6736(02) 07953-9

Cunningham, A. F., Johnston, S. L., Julious, S. A., Lampe, F. C., and Ward, M. E. (1998). Chronic Chlamydia pneumoniae infection and asthma exacerbations in children. Eur. Respir. I. 11, 345-349. doi: 10.1183/ 09031936.98.11020345

Dawson-Caswell, M., and Muncie, H. L. Jr. (2011). Respiratory syncytial virus infection in children. Am. Fam. Physician 83, 141-146.

Dimopoulos, G., Lerikou, M., Tsiodras, S., Chranioti, A., Perros, E., Anagnostopoulou, U., et al. (2012). Viral epidemiology of acute exacerbations of chronic obstructive pulmonary disease. Pulm. Pharmacol. Ther. 25, 12-18. doi: 10.1016/j.pupt.2011. 08.004

Donaldson, G. C., Seemungal, T. A., Bhowmik, A., and Wedzicha, J. A. (2002). Relationship between exacerbation frequency and lung function decline in chronic obstructive pulmonary disease. Thorax 57 , 847-852. doi: 10.1136/thorax.57. 10.847

Dougherty, R. H., and Fahy, J. V. (2009). Acute exacerbations of asthma: epidemiology, biology and the exacerbation-prone phenotype. Clin. Exp. Allergy 39, 193 202. doi: $10.1111 / j .1365-2222.2008$. 03157.x
Edwards, M. R., Bartlett, N. W., Hussell, T., Openshaw, P., and Johnston, S. L. (2012). The microbiology of asthma. Nat. Rev. Microbiol. 10, 459-471. doi: 10.1038/ nrmicro2801

Fahy, J. V. (2002). Goblet cell and mucin gene abnormalities in asthma. Chest 122, 320S-326S. doi: 10.1378/ chest.122.6_suppl.320S

Falsey, A. R., Formica, M. A., Hennessey, P. A., Criddle, M. M., Sullender, W. M., and Walsh, E. E. (2006). Detection of respiratory syncytial virus in adults with chronic obstructive pulmonary disease. Am. J. Respir. Crit. Care Med. 173 639-643. doi: 10.1164/rccm.200510$16810 \mathrm{C}$

Falsey, A. R., Formica, M. A., and Walsh, E. E. (2012). Yield of sputum for viral detection by reverse transcriptase PCR in adults hospitalized with respiratory illness. J. Clin. Microbiol. 50, 21-24. doi: 10.1128/JCM. 05841-11

Fujitsuka, A., Tsukagoshi, H., Arakawa, M., Goto-Sugai, K., Ryo, A., Okayama, Y., et al. (2011). A molecular epidemiological study of respiratory viruses detected in Japanese children with acute wheezing illness. BMC Infect. Dis. 11:168. doi 10.1186/1471-2334-11-168

Gendrel, D., Guedj, R., Pons-Catalano, C., Emirian, A., Raymond, J., Rozenberg, F., etal. (2007). Human bocavirus in children with acute asthma. Clin. Infect. Dis 45, 404-405. doi: 10.1086/519505

Greenberg, S. B., Allen, M., Wilson, J., and Atmar, R. L. (2000). Respiratory viral infections in adults with and without chronic obstructive pulmonary disease. Am. J. Respir. Crit. Care Med. 162, 167-173. doi: 10.1164/ajrccm.162.1. 9911019

Groenewegen, K. H., Schols, A. M., and Wouters, E. F. (2003). Mortality and mortality-related factors after hospitalization for acute exacerbation of COPD. Chest 124, 459-467. doi: 10.1378/chest.124. 2.459

Groskreutz, D. J., Monick, M. M., Powers, L. S., Yarovinsky, T. O., Look, D. C., and Hunninghake, G. W. (2006). Respiratory syncytial virus induces TLR3 protein and protein kinase R, leading to increased double-stranded RNA responsiveness in airway epithelial cells. J. Immunol. 176, 17331740.

Hardin, M., Silverman, E. K., Barr R. G., Hansel, N. N., Schroeder J. D., Make, B. J., et al. (2011). The clinical features of the overlap between COPD and asthma. Respir. Res. 12, 127. doi: 10.1186/1465-992112-127

Harper, S. A., Bradley, J. S., Englund, J. A., File, T. M., Gravenstein, S. Hayden, F. G., et al. (2009). Seasonal influenza in adults and childrendiagnosis, treatment, chemoprophylaxis, and institutional outbreak management: clinical practice guidelines of the Infectious Disease Society of America. Clin. Infect. Dis 48, 1003-1032. doi: 10.1086/ 598513

Hashimoto, S., Matsumoto, K., Gon, Y., Ichiwata, T., Takahashi, N., and Kobayashi, T. (2008). Viral infection in asthma. Allergol. Int. 57, 21-31. doi: 10.2332/allergolint.R07-156

Henderson, F. W., Clyde, W. A. Jr., Collier, A. M., Denny, F. W., Senior, R. J., Sheaffer, C. I., et al (1979). The etiologic and epidemiologic spectrum of bronchiolitis in pediatric practice. J. Pediatr. 95, 183 190. doi: 10.1016/S0022-3476(79) 80647-2

Hirota, T., Takahashi, A., Kubo, M., Tsunoda, T., Tomita, K., Doi, S. et al. (2011). Genome-wide association study identifies three new susceptibility loci for adult asthma in the Japanese population. Nat. Genet. 43, 893-896. doi: 10.1038/ ng.887

Hogg, J. C., Chu, F., Utokaparch, S., Woods, R., Elliott, W. M., Buzatu, L., etal. (2004). The nature of small-airway obstruction in chronic obstructive pulmonary disease. N. Engl. J. Med. 350, 2645-2653. doi: 10.1056/NEJMoa 032158

Holtzman, M. J. (2012). Asthma as a chronic disease of the innate and adaptive immune systems responding to viruses and allergens. $J$. Clin. Invest. 122, 2741-2748. doi: 10.1172/JCI60325

Hospers, J. J., Postma, D. S., Rijcken, B., Weiss, S. T., and Schouten, J. P. (2000). Histamine airway hyperresponsiveness and mortality from chronic obstructive pulmonary disease: a cohort study. Lancet 356, 1313-1317. doi: 10.1016/S0140-6736 (00)02815-4

Hurst, J. R., Vestbo, J., Anzueto, A., Locantore, N., Mullerova, H., TalSinger, R., et al. (2010). Susceptibility to exacerbation in chronic obstructive pulmonary disease. N. Engl. J. Med. 363, 1128-1138. doi: 10.1056/ NEJMoa0909883

Hutchinson, A. F., Ghimire, A. K. Thompson, M. A., Black, J. F., Brand, C. A., Lowe, A. J., et al.
(2007). A community-based, timematched, case-control study of respiratory viruses and exacerbations of COPD. Respir. Med. 101, 24722481. doi: 10.1016/j.rmed.2007. 07.015

Iesato, K., Tatsumi, K., Saito, K., Ogasawara, T., Sakao, S., Tada, Y., et al. (2008). Tiotropium bromide attenuates respiratory syncytial virus replication in epithelial cells. Respiration 76, 434-441. doi: 10.1159/ 000151729

Jackson, D. J., Evans, M. D., Gangnon, R. E., Tisler, C. J., Pappas, T. E., Lee, W. M., et al. (2012). Evidence for a causal relationship between allergic sensitization and rhinovirus wheezing in early life. Am. J. Respir. Crit. Care Med. 185, 281-285. doi: 10.1164/rccm.2011040660OC

Jackson, D. J., Gangnon, R. E., Evans, M. D., Roberg, K. A., Anderson, E. L., Pappas, T. E., et al. (2008). Wheezing rhinovirus illnesses in early life predict asthma development in high-risk children. Am. J. Respir. Crit. Care Med. 178, 667-672. doi: 10.1164/rccm.200802309OC

Jackson, D. J., and Johnston, S. L. (2010). The role of viruses in acute exacerbations of asthma. J. Allergy Clin. Immunol. 125, 1178-1187. doi: 10.1016/j.jaci.2010.04.021

Johnston, N. W., and Sears, M. R. (2006). Asthma exacerbations. 1: epidemiology. Thorax 61, 722-728. doi: 10.1136/thx.2005.045161

Johnston, S. L., Pattemore, P. K., Sanderson, G., Smith, S., Campbell, M. J., Josephs, L. K., et al. (1996). The relationship between upper respiratory infections and hospital admissions for asthma: a time-trend analysis. Am. J. Respir. Crit. Care Med. 154, 654-660. doi: 10.1164/ajrccm.154. 3.8810601

Johnston, S. L., Pattemore, P. K., Sanderson, G., Smith, S., Lampe, F., Josephs, L., et al. (1995). Community study of role of viral infections in exacerbations of asthma in 9-11 year old children. BMJ 310, 12251229. doi: 10.1136/bmj.310.6989. 1225

Kaiser, L., Wat, C., Mills, T., Mahoney, P., Ward, P., and Hayden, F. (2003). Impact of oseltamivir treatment on influenza-related lower respiratory tract complications and hospitalizations. Arch. Intern. Med. 163, 16671672. doi: 10.1001/archinte.163. 14.1667

Kaplan, A. G., Balter, M. S., Bell, A. D., Kim, H., and Mcivor, R. A. (2009). Diagnosis of asthma in adults. CMAJ, 
181, E210-E220. doi: 10.1503/cmaj. 080006

Keatings, V. M., Collins, P. D., Scott, D. M., and Barnes, P. J. (1996). Differences in interleukin-8 and tumor necrosis factor-alpha in induced sputum from patients with chronic obstructive pulmonary disease or asthma. Am. J. Respir. Crit. Care Med. 153, 530 534. doi: 10.1164/ajrccm.153.2. 8564092

Kerstjens, H. A., Engel, M., Dahl, R., Paggiaro, P., Beck, E., Vandewalker, M., et al. (2012). Tiotropium in asthma poorly controlled with standard combination therapy. N. Engl. J. Med. 367, 1198-1207. doi: 10.1056/NEJMoa 1208606

Kherad, O., Kaiser, L., Bridevaux, P. O., Sarasin, F., Thomas, Y., Janssens, J. P., et al. (2010). Upperrespiratory viral infection, biomarkers, and COPD exacerbations. Chest 138, 896-904. doi: 10.1378/chest.092225

Ko, F. W., Ip, M., Chan, P. K., Chan, M. C., To, K. W., Ng, S. S., et al. (2007). Viral etiology of acute exacerbations of COPD in Hong Kong. Chest 132, 900-908. doi: 10.1378/chest. 07-0530

Kraft, M. (2006). Asthma and chronic obstructive pulmonary disease exhibit common origins in any country! Am. J. Respir. Crit. Care Med. 174, 238-240. doi: 10.1164/rccm.2604007

Kraft, M., Adler, K. B., Ingram, J. L., Crews, A. L., Atkinson, T. P., Cairns, C. B., et al. (2008). Mycoplasma pneumoniae induces airway epithelial cell expression of MUC5AC in asthma. Eur. Respir. J. 31, 43-46. doi: 10.1183/09031936.00103307

Kusel, M. M., De Klerk, N. H., Kebadze, T., Vohma, V., Holt, P. G., Johnston, S. L., et al. (2007). Early-life respiratory viral infections, atopic sensitization, and risk of subsequent development of persistent asthma. J. Allergy Clin. Immunol. 119, 1105-1110. doi: 10.1016/j.jaci.2006. 12.669

Lee, F. E., Walsh, E. E., and Falsey, A. R. (2011). The effect of steroid use in hospitalized adults with respiratory syncytial virus-related illness. Chest 140, 1155-1161. doi: 10.1378/chest.11-0047

Lieberman, D., Shimoni, A., KerenNaus, A., Steinberg, R., and Shemer-Avni, Y. (2009). Identification of respiratory viruses in adults: nasopharyngeal versus oropharyngeal sampling. J. Clin. Microbiol. 47, 3439-3443. doi: 10.1128/JCM. 00886-09
Louie, S., Zeki, A. A., Schivo, M., Chan, A. L., Yoneda, K. Y., Avdalovic, M., etal. (2013). The asthmachronic obstructive pulmonary disease overlap syndrome: pharmacotherapeutic considerations. Expert Rev. Clin. Pharmacol. 6, 197-219. doi: 10.1586/ecp.13.2

Macek, V., Sorli, J., Kopriva, S., and Marin, J. (1994). Persistent adenoviral infection and chronic airway obstruction in children. Am. J. Respir Crit. Care Med. 150, 7-10. doi: 10.1164/ajrccm.150.1.8025775

Magnussen, H., Bugnas, B., Van Noord, J., Schmidt, P., Gerken, F., and Kesten, S. (2008). Improvements with tiotropium in COPD patients with concomitant asthma. Respir. Med. 102, 50-56. doi: 10.1016/j.rmed.2007.08.003

Mallia, P., Footitt, J., Sotero, R., Jepson, A., Contoli, M., Trujillo-Torralbo, M. B., et al. (2012). Rhinovirus infection induces degradation of antimicrobial peptides and secondary bacterial infection in chronic obstructive pulmonary disease. Am. J. Respir. Crit. Care Med. 186, 1117-1124. doi: 10.1164/rccm.201205-0806OC

Mallia, P., Message, S. D., Gielen, V., Contoli, M., Gray, K., Kebadze, T., et al. (2011). Experimental rhinovirus infection as a human model of chronic obstructive pulmonary disease exacerbation. Am. J. Respir. Crit. Care Med. 183, 734-742. doi: 10.1164/rccm.2010060833 OC

McErlean, P., Greiman, A., Favoreto, S. Jr., and Avila, P. C. (2010). Viral diversity in asthma. Immunol. Allergy Clin. North Am. 30, 481-95, v. doi: 10.1016/j.iac.2010.08.001

McManus, T. E., Marley, A. M., Baxter, N., Christie, S. N., O'neill, H. J., Elborn, J. S., et al. (2008). Respiratory viral infection in exacerbations of COPD. Respir. Med. 102, 1575-1580. doi: 10.1016/j.rmed.2008.06.006

Message, S. D., Laza-Stanca, V., Mallia, P., Parker, H. L., Zhu, J., Kebadze, T., et al. (2008). Rhinovirus-induced lower respiratory illness is increased in asthma and related to virus load and Th1/2 cytokine and IL10 production. Proc. Natl. Acad. Sci. U.S.A. 105, 13562-13567. doi: 10.1073/pnas.0804181105

Miravitlles, M., Murio, C., Guerrero, T., and Gisbert, R. (2002). Pharmacoeconomic evaluation of acute exacerbations of chronic bronchitis and COPD. Chest 121, 1449-1455. doi: 10.1378/chest.121.5.1449

Murray, C. S., Simpson, A., and Custovic, A. (2004). Allergens, viruses, and asthma exacerbations. Proc.
Am. Thorac. Soc. 1, 99-104. doi: 10.1513/pats.2306027

Nagel, M. A., Cohrs, R. J., Mahalingam, R., Wellish, M. C., Forghani, B. Schiller, A., et al. (2008). The varicella zoster virus vasculopathies: clinical, CSF, imaging, and virologic features. Neurology 70, 853-860. doi: $10.1212 / 01 . w n l .0000304747$. 38502.e8

National Asthma Education and Prevention Program. (2007). Expert Panel Report 3 (EPR-3): Guidelines for the Diagnosis and Management of Asthma-Summary Report 2007. J. Allergy Clin. Immunol. 120(Suppl. 5), S94-S138. doi: 10.1016/j. jaci.2007.09.029

Nichol, K. L., Nordin, J. D., Nelson, D. B., Mullooly, J. P., and Hak, E. (2007). Effectiveness of influenza vaccine in the community-dwelling elderly. $\mathrm{N}$. Engl. J. Med. 357, 1373-1381. doi: 10.1056/NEJMoa070844

Nicholson, K. G., Kent, J., and Ireland, D. C. (1993). Respiratory viruses and exacerbations of asthma in adults. BMJ 307, 982-986. doi: 10.1136/bmj.307.6910.982

Nisar, N., Guleria, R., Kumar, S., Chand Chawla, T., and Ranjan Biswas, N. (2007). Mycoplasma pneumoniae and its role in asthma. Postgrad. Med. J. 83, 100-104. doi: 10.1136/ pgmj.2006.049023

Ober, C., and Yao, T. C. (2011) The genetics of asthma and allergic disease: a 21st century perspective. Immunol. Rev. 242, 10-30. doi 10.1111/j.1600-065X.2011.01029.x

O’Byrne, P. M., Barnes, P. J., RodriguezRoisin, R., Runnerstrom, E., Sandstrom, T., Svensson, K., et al. (2001). Low dose inhaled budesonide and formoterol in mild persistent asthma: the OPTIMA randomized trial. Am. J. Respir. Crit. Care Med. 164, 1392-1397. doi: 10.1164/ajrccm.164.8.2104102

Olenec, J. P., Kim, W. K., Lee, W. M., Vang, F., Pappas, T. E., Salazar, L. E., et al. (2010). Weekly monitoring of children with asthma for infections and illness during common cold seasons. J. Allergy Clin. Immunol. 125, 1001-1006.e1. doi: 10.1016/j.jaci.2010.01.059

Olszewska, W., and Openshaw, P. (2009). Emerging drugs for respiratory syncytial virus infection. Expert Opin. Emerg. Drugs 14, 207-217. doi: 10.1517/14728210902946399

Ong, B. H., Gao, Q., Phoon, M. C., Chow, V. T., Tan, W. C., and Van Bever, H. P. (2007). Identification of human metapneumovirus and Chlamydophila pneumoniae in children with asthma and wheeze in Singapore. Singapore Med. J. 48, 291-293.

Openshaw, P. J. (1995). Immunopathological mechanisms in respiratory syncytial virus disease. Springer Semin. Immunopathol. 17, 187-201. doi: 10.1007/BF00196165

O'Sullivan, S. M. (2005). Asthma death, CD8+ T cells, and viruses. Proc. Am. Thorac. Soc. 2, 162165. doi: 10.1513/pats.200502016AW

Papi, A., Bellettato, C. M., Braccioni, F., Romagnoli, M., Casolari, P., Caramori, G., et al. (2006). Infections and airway inflammation in chronic obstructive pulmonary disease severe exacerbations. Am. J. Respir. Crit. Care Med. 173, 11141121. doi: 10.1164/rccm.2005068590C

Perera, W. R., Hurst, J. R., Wilkinson, T. M., Sapsford, R. J., Mullerova, H., Donaldson, G. C., et al. (2007). Inflammatory changes, recovery and recurrence at COPD exacerbation. Eur. Respir. J. 29, 527-534. doi: 10.1183/09031936.000 92506

Perotin, J. M., Dury, S., Renois, F., Deslee, G., Wolak, A., Duval, V., etal. (2013). Detection of multiple viral and bacterial infections in acute exacerbation of chronic obstructive pulmonary disease: a pilot prospective study. J. Med. Virol. 85, 866-873. doi: 10.1002/jmv. 23495

Poole, P. J., Chacko, E., WoodBaker, R. W., and Cates, C. J. (2000). Influenza vaccine for patients with chronic obstructive pulmonary disease. Cochrane Database Syst. Rev. CD002733. doi: 10.1002/14651858.CD002733

Rakes, G. P., Arruda, E., Ingram, J. M., Hoover, G. E., Zambrano, J. C., Hayden, F. G., etal. (1999). Rhinovirus and respiratory syncytial virus in wheezing children requiring emergency care. IgE and eosinophil analyses. Am. J. Respir. Crit. Care Med. 159, 785-790. doi: 10.1164/ajrccm.159.3.9801052

Reddel, H. K., Taylor, D. R., Bateman, E. D., Boulet, L. P., Boushey, H. A., Busse, W. W., et al. (2009). An official American Thoracic Society/European Respiratory Society statement: asthma control and exacerbations: standardizing endpoints for clinical asthma trials and clinical practice. Am. J. Respir. Crit. Care Med. 180, 59-99. doi: 10.1164/rccm.200801-060ST

Redhu, N. S., and Gounni, A. S. (2012). Function and mechanisms of TSLP/TSLPR complex in asthma and 
COPD. Clin. Exp. Allergy 42, 994 1005. doi: 10.1111/j.1365-2222.2011. 03919.x

Rohde, G., Wiethege, A., Borg, I., Kauth, M., Bauer, T. T., Gillissen, A., et al. (2003). Respiratory viruses in exacerbations of chronic obstructive pulmonary disease requiring hospitalisation: a case-control study. Tho$\operatorname{rax} 58,37-42$. doi: 10.1136/thorax. 58.1.37

Saetta, M., Di Stefano, A., Maestrelli, P., Turato, G., Ruggieri, M. P., Roggeri, A., etal. (1994). Airway eosinophilia in chronic bronchitis during exacerbations. Am. J. Respir. Crit. Care Med. 150, 16461652. doi: 10.1164/ajrccm.150.6. 7952628

Sapey, E., and Stockley, R. A. (2006). COPD exacerbations. 2: aetiology. Thorax 61, 250-258. doi: 10.1136/ thx.2005.041822

Seemungal, T., Harper-Owen, R., Bhowmik, A., Moric, I., Sanderson, G., Message, S., et al. (2001). Respiratory viruses, symptoms, and inflammatory markers in acute exacerbations and stable chronic obstructive pulmonary disease. Am. J. Respir. Crit. Care Med. 164, 16181623. doi: 10.1164/ajrccm.164.9. 2105011

Seemungal, T. A., Donaldson, G. C., Paul, E. A., Bestall, J. C., Jeffries, D. J., and Wedzicha, J. A. (1998). Effect of exacerbation on quality of life in patients with chronic obstructive pulmonary disease. Am. J. Respir. Crit. Care Med. 157, 14181422. doi: 10.1164/ajrccm.157.5. 9709032

Seemungal, T. A., Hurst, J. R., and Wedzicha, J. A. (2009). Exacerbation rate, health status and mortality in COPD-a review of potential interventions. Int. J. Chron. Obstruct. Pulmon. Dis. 4, 203-223. doi: 10.2147/ COPD.S3385

Sethi, S., Evans, N., Grant, B. J., and Murphy, T. F. (2002). New strains of bacteria and exacerbations of chronic obstructive pulmonary disease. N. Engl. J. Med. 347, 465-471. doi: 10.1056/NEJMoa 012561

Sethi, S., and Murphy, T. F. (2008). Infection in the pathogenesis and course of chronic obstructive pulmonary disease. N. Engl. J. Med. 359, 2355-2365. doi: 10.1056/ NEJMra0800353

Silva, G. E., Sherrill, D. L., Guerra, S., and Barbee, R. A. (2004). Asthma as a risk factor for COPD in a longitudinal study. Chest
126, 59-65. doi: 10.1378/chest.126. 1.59

Tan, W. C. (2005). Viruses in asthma exacerbations. Curr. Opin. Pulm. Med. 11, 21-26.

Tan, W. C., Xiang, X., Qiu, D., $\mathrm{Ng}, \quad$ T. P., Lam, S. F., and Hegele, R. G. (2003). Epidemiology of respiratory viruses in patients hospitalized with near-fatal asthma, acute exacerbations of asthma, or chronic obstructive pulmonary disease. Am. J. Med. 115, 272277. doi: 10.1016/S0002-9343(03) 00353-X

Tashkin, D. P., Celli, B., Senn, S., Burkhart, D., Kesten, S., Menjoge, S., etal. (2008). A 4-year trial of tiotropium in chronic obstructive pulmonary disease. N. Engl. J. Med. 359, 1543-1554. doi: 10.1056/NEJMoa0805800

Tashkin, D. P., Pearle, J., Iezzoni, D., and Varghese, S. T. (2009). Formoterol and tiotropium compared with tiotropium alone for treatment of COPD. COPD 6, 17-25. doi: 10.1080/1541255090 2724073

Teichtahl, H., Buckmaster, N., and Pertnikovs, E. (1997). The incidence of respiratory tract infection in adults requiring hospitalization for asthma. Chest 112, 591-596. doi: $10.1378 /$ chest.112.3.591

Tokuda, Y., and Miyagi, S. (2007). Physical diagnosis of chronic obstructive pulmonary disease. Intern. Med. 46, 1885-1891. doi: 10.2169/internalmedicine.46.0455

Vallet, C., Pons-Catalano, C., Mandelcwajg, A., Wang, A., Raymond, J., Lebon, P., et al. (2009). Human bocavirus: a cause of severe asthma exacerbation in children. J. Pediatr. 155, 286-288. doi: 10.1016/j. jpeds.2009.01.069

Vestbo, J., Hurd, S. S., Agusti, A. G., Jones, P. W., Vogelmeier, C., Anzueto, A., et al. (2013). Global strategy for the diagnosis, management, and prevention of chronic obstructive pulmonary disease: GOLD executive summary. Am. J. Respir. Crit. Care Med. 187, 347-365. doi: 10.1164/rccm.2012040596PP

Vlahakis, N. E., and Aksamit, T. R. (2001). Diagnosis and treatment of allergic bronchopulmonary aspergillosis. Mayo Clin. Proc 76, 930-938. doi: 10.1016/S00256196(11)62114-9

Vogelmeier, C., Hederer, B., Glaab, T., Schmidt, H., Rutten-Van Molken, M. P., Beeh, K. M., et al. (2011).
Tiotropium versus salmeterol for the prevention of exacerbations of COPD. N. Engl. J. Med. 364 1093-1103. doi: 10.1056/NEJMoal 008378

Wedzicha, J. A., Calverley, P. M., Seemungal, T. A., Hagan, G., Ansari, Z., and Stockley, R. A. (2008). The prevention of chronic obstructive pulmonary disease exacerbations by salmeterol/fluticasone propionate or tiotropium bromide. Am. J. Respir. Crit. Care Med. 177, 19-26. doi: 10.1164/rccm.200707973OC

Wenzel, S. E., Schwartz, L. B., Langmack, E. L., Halliday, J. L., Trudeau, J. B., Gibbs, R. L., etal. (1999). Evidence that severe asthma can be divided pathologically into two inflammatory subtypes with distinct physiologic and clinical characteristics. Am. J. Respir. Crit. Care Med. 160, 10011008. doi: 10.1164/ajrccm.160.3 9812110

Wilkinson, T. M., Donaldson, G. C., Johnston, S. L., Openshaw, P. J., and Wedzicha, J. A. (2006a). Respiratory syncytial virus, airway inflammation, and FEV1 decline in patients with chronic obstructive pulmonary disease. Am. J. Respir. Crit. Care Med. 173, 871-876. doi 10.1164/rccm.200509-1489OC

Wilkinson, T. M., Hurst, J. R., Perera, W. R., Wilks, M., Donaldson, G. C., and Wedzicha, J. A. (2006b). Effect of interactions between lower airway bacterial and rhinoviral infection in exacerbations of COPD. Chest 129, 317-324. doi: 10.1378/chest.129.2.317

Williams, J. V., Crowe, J. E. Jr., Enriquez, R., Minton, P., Peebles, R. S. Jr., Hamilton, R. G., et al. (2005). Human metapneumovirus infection plays an etiologic role in acute asthma exacerbations requiring hospitalization in adults. J. Infect. Dis. 192, 1149-1153. doi: 10.1086/ 444392

Xepapadaki, P., Koutsoumpari, I., Papaevagelou, V., Karagianni, C., and Papadopoulos, N. G. (2008). Atypical bacteria and macrolides in asthma. Allergy Asthma Clin. Immunol. 4, 111-116. doi: 10.1186/1710-1492-43-111

Xepapadaki, P., and Papadopoulos, N. G. (2010). Childhood asthma and infection: virus-induced exacerbations as determinants and modifiers. Eur. Respir. J. 36 438-445. doi: 10.1183/09031936. 00149009
Xiang, X., Qiu, D., Chan, K. P., Chan, S. H., Hegele, R. G., and Tan, W. C. (2002). Comparison of three methods for respiratory virus detection between induced sputum and nasopharyngeal aspirate specimens in acute asthma. J. Virol. Methods 101, 127133. doi: 10.1016/S0166-0934(01) 00431-1

Yamaya, M., Azuma, A., Takizawa, H., Kadota, J., Tamaoki, J., and Kudoh, S. (2012a). Macrolide effects on the prevention of COPD exacerbations. Eur. Respir. J. 40, 485-494. doi: 10.1183/09031936.00208011

Yamaya, M., Nishimura, H., Hatachi, Y., Yasuda, H., Deng, X., Sasaki, T., et al. (2012b). Inhibitory effects of tiotropium on rhinovirus infection in human airway epithelial cells. Eur. Respir. J. 40, 122-132. doi: 10.1183/09031936. 00065111

Yerkovich, S. T., Hales, B. J., Carroll, M. L., Burel, J. G., Towers, M. A., Smith, D. J., et al. (2012). Reduced rhinovirus-specific antibodies are associated with acute exacerbations of chronic obstructive pulmonary disease requiring hospitalisation. BMC Pulm. Med. 12:37. doi: 10.1186/1471-2466-12-37

Conflict of Interest Statement: The authors declare that the research was conducted in the absence of any commercial or financial relationships that could be construed as a potential conflict of interest.

Received: 30 June 2013; accepted: 10 September 2013; published online: 01 October 2013.

Citation: Kurai D, Saraya T, Ishii $H$ and Takizawa $H$ (2013) Virus-induced exacerbations in asthma and COPD. Front. Microbiol. 4:293. doi: 10.3389/ fmicb.2013.00293

This article was submitted to Virology, a section of the journal Frontiers in Microbiology.

Copyright (c) 2013 Kurai, Saraya, Ishii and Takizawa. This is an open-access article distributed under the terms of the Creative Commons Attribution License (CC BY). The use, distribution or reproduction in other forums is permitted, provided the original author(s) or licensor are credited and that the original publication in this journal is cited, in accordance with accepted academic practice. No use, distribution or reproduction is permitted which does not comply with these terms. 